\title{
Measuring the Business Environment for Entrepreneurship in Fragile States
}

\author{
Chiara Guglielmetti*
}

March 2010

\begin{abstract}
This paper aims towards better understanding the role of entrepreneurship in fragile states, which despite the practical interest and relevance has been somewhat disregarded in academic research. Given the necessity to support policy formulation with appropriate and relevant measurement of entrepreneurship and the business environment, the primary focus in this paper is to scrutinize existing international indicators, in particular the World Bank's Doing Business (DB) indicators and ask whether they are able to capture entrepreneurial dynamics and constructively guide policy-making towards entrepreneurship in fragile state.

The paper argues that DB indicators give a partial picture of the nexus between institutional context, policy reforms, entrepreneurship and economic development. In particular, DB indicators' analysis fails to address three pivotal aspects: first, the process through which individuals become entrepreneurs, second, industrial cooperative and competitive relationships both intersectoral and across different sectors of the economy, and third, the characteristics of workers employed in enterprises. .../
\end{abstract}

Keywords: entrepreneurship, development, fragile states, institutions, business environment

JEL classification: L25, L26, O10, O12

\section{Copyright (C) UNU-WIDER 2010}

* University of Trento, email: chiara.guglielmetti@unitn.it

This study has been prepared within the UNU-WIDER project on Entrepreneurship and Development (Promoting Entrepreneurial Capacity), directed by Wim Naudé.

UNU-WIDER acknowledges the financial contributions to the research programme by the governments of Denmark (Royal Ministry of Foreign Affairs), Finland (Ministry for Foreign Affairs), Sweden (Swedish International Development Cooperation Agency-Sida) and the United Kingdom (Department for International Development). 
Consequently, DB indicators are not able to capture innovation and changing processes, and miss some pivotal features of both the internal and the external environment of the enterprise. The paper maintains that these shortcomings are particularly serious when referred to fragile countries and discusses how and to what extent DB indicators lead to adverse effect policy recommendations, being inadequate for policy planning in fragile areas.

Tables appear at the end of the paper.

The World Institute for Development Economics Research (WIDER) was established by the United Nations University (UNU) as its first research and training centre and started work in Helsinki, Finland in 1985. The Institute undertakes applied research and policy analysis on structural changes affecting the developing and transitional economies, provides a forum for the advocacy of policies leading to robust, equitable and environmentally sustainable growth, and promotes capacity strengthening and training in the field of economic and social policy making. Work is carried out by staff researchers and visiting scholars in Helsinki and through networks of collaborating scholars and institutions around the world.

www.wider.unu.edu publications@wider.unu.edu

UNU World Institute for Development Economics Research (UNU-WIDER)

Katajanokanlaituri 6 B, 00160 Helsinki, Finland

Typescript prepared by Lisa Winkler at UNU-WIDER

The views expressed in this publication are those of the author(s). Publication does not imply endorsement by the Institute or the United Nations University, nor by the programme/project sponsors, of any of the views expressed. 


\section{Introduction}

More than a billion people live in around 50 developing countries which have been described as 'fragile states' (Naudé et al. 2008). In fragile states, governments lack the authority, legitimacy and often the willingness to promote economic development. According to Binzel and Brück (2007: 5) fragility refers to 'the existence of persistent, systematic, significant and interrelated social, political and economic uncertainties'. Increasingly, donors and international development agencies are turning to private sector development where state capacity is lacking. Promoting entrepreneurship in fragile states, and in conflict and post-conflict situations, has therefore assumed high importance in strategies dealing with fragile states (Addison and Brück 2009; Anand 2009; Naudé 2009a, 2009b).

This paper aims to contribute to a greater understanding of the role of entrepreneurship in fragile states, which despite the practical interest and relevance, has been somewhat disregarded in academic research. Given the necessity to support policy formulation with appropriate and relevant measurement of entrepreneurship and the business environment, the primary focus in this paper is on scrutinizing the World Bank's (WB) Doing Business (DB) indicators and ask whether they are able to capture entrepreneurial dynamics and constructively guide policy-making towards entrepreneurship in fragile states.

We are assisting to a collective claim among scholars and practitioners in entrepreneurship policy on the fact that 'the level and quality of entrepreneurship make a difference in the economic vitality of communities, regions, industries and the nation as a hole' (Hart 2003: 4; Baumol 2009; Kanniainen and Keuschnigg 2005; Malecki 1994). Nevertheless, in the literature awareness is growing about the strong need of empirical studies that assess the direction and the interaction between entrepreneurs, policy, institutions and context, instead of taking for granted the positive effect of entrepreneurship - employed as a sort of 'umbrella' concept - on development and prosperity (Shane 2008), leaving apart, for example, impacts on the environment and the ambiguous role of entrepreneurship in conflict dynamics. Fragile and post-conflict state policy priorities may differ from those of non-conflict affected countries because the necessities per se are different, but also because problems are atypically severe and they are atypically sensitive to specific reform processes (Collier and Hoeffler 2002).

International indicators of the quality of institutions are becoming influential for policymakers and governments. In particular, the $\mathrm{DB}$, of which seven successive editions have been released up to now $^{1}$, is gaining momentum in the academic debate as well as in the political arena. The outreach of DB indicators to fragile states has been eased by their wide geographical coverage. Designed to measure the determinants of entrepreneurial activity and to recommend suitable institutional and political reforms in 183 countries (DB 2010), the DB indicators represent a precious, and often unique, access to information, in particular in countries which lack adequate and reliable data on business environment and performance.

The relevance of DB is twofold: both positive and normative. DB reports claim transparency in providing updated and far reaching (unbalanced) panel data and ranking the countries according to ten dimensions through a 'new approach to the measurement' of the ease of doing business (IBRD and WB 2004). The principal aim of the indicators, however, is 'to guide reform of the scope and efficiency of government regulation' in order to foster entrepreneurship and thus promote economic, social and human development. The first DB report explicitly stresses the normative function of the index: the purposes of DB are to encourage reforms through country benchmarking,

1 IBRD and WB 2004, 2005, 2006, 2007, 2008a, 2008c and 2009; WB 2002. 
inform the design of the reforms, enrich international initiatives on development effectiveness and inform theory (IBRD and WB 2004).

About one-third of the countries reviewed by DB can be considered fragile and in conflict. ${ }^{2}$ Many fragile states are mired in conflict, or just entering into a post-conflict phase, or have histories of long and deep conflict. Understanding the dynamics of development in such states has become a defining global challenge, as there is agreement that little progress will be made in terms of achieving progress in the areas of global public goods such as addressing security, climate change and migration unless the issue of fragile states are addressed.

This notwithstanding, the DB indicators do not explicitly deal with the relationship between conflict or state fragility and entrepreneurship. As far as a mere linguistic analysis is concerned, the terms 'conflict' and 'post-conflict' appear once in DB 2009 for the first time in all the DB report series. Even in regional or national reports, DB does not consider any context variables. The DB approach is based upon a standard vision of the development process, according to which progressive interaction and integration of economies lead to a convergence of institutional and political solutions, practices and standards.

As underlined by Naudé (2009b), the scarce availability of data on entrepreneurship in countries affected by conflict dynamics places a significant constraint on both research and policy design. Yet, paradoxically, DB indicators tend to acquire more attention in fragile or conflict prone countries. It is worth noting that the WB has been using DB data in establishing conditions towards its debtors and that the International Development Association (IDA) has set a business regulatory environment as one of the criteria in the country policy and institutional assessment. ${ }^{3}$ Moreover, the Millennium Challenge Corporation ${ }^{4}$ (MCC) also relies on DB data to build its six governance indicators 5 for the eligibility of assistance programmes and for the Millennium Challenge Account selection criteria (MCC 2003, 2004, 2005, 2006, 2007, 2008, 2009 and 2010).

The criticism of the DB approach advanced in this paper is twofold. First, the development process is traced by the interaction between forces that are meant to generate a progressive convergence. DB upholds a strategy of development which neither contextualizes information nor interprets it accordingly, disregarding the role of historical, institutional and cultural heritage, which is often only anecdotically evocated. Recent literature underlines the necessity of a full recognition of the unique characteristics of emerging economies (Bruton et al. 2008) and the importance of developing new theories to understand entrepreneurship, and doing business, in different contexts. Examining the relationship between specific economic environments and public policy is crucial in identifying key barriers to economic and social development (Rodrik 2007). The context in which economic agents act varies in terms of opportunities, constraints and incentives, and exerts a strong influence on individual behaviour. Second, through an interplay of simplification, measurement and convergence, DB risks becoming a race-to-the-bottom in various crucial institutional and political features in which the pivotal role of pro-active public policies in entrepreneurship development is disregarded.

2 In 2010 about 23 out of 183 countries reviewed by DB can be considered in conflict and 41 can be considered postconflict countries.

3 See the Assessment Questionnaire of the IDA, Business Regulatory Environment criterion (IDA 2007: 16) and the case of Afghan reforms on procedures to start up a business, financed by USAID (DB 2007).

4 The MCC, a US government corporation established in 2004, is responsible for the stewardship of the MCA, funded by the Congress with the aim of channelling funds to developing countries.

5 The business start up indicator (made up of the DB indicators costs to start a business and days to start a business combined with equal weight) and the days to register property and cost of registering property indicators (two of the three indicators which make up land rights and access indicator) use as sources DB data. 
The remainder of this paper will proceed as follows. The next section discusses pivotal issues in the interplay of institutions, public policy and entrepreneurship in fragile and post-conflict states. Then, in Sections 3 and 4, the DB indicators will be analysed in the light of fragile and post-conflict states. Section 5 concludes discussing how and to what extent DB indicators lead to 'adverse effect' policy recommendations. In particular, DB indicators give a partial picture of the nexus between institutional context, policy reforms, entrepreneurship and economic development and fail in addressing pivotal aspects as the process through which individuals become entrepreneurs, the ambiguous role of entrepreneurship in a fragile environment, the relationships between enterprises, both intersectoral and across different sectors of the economy, and the characteristics of workers employed in enterprises. In doing so, DB fails to capture firm internal and external contexts, and thus does not trace innovation, which should be at the core of a Schumpeterian entrepreneurial economy.

\section{The business environment in fragile and post-conflict states}

A comprehensive analysis of the characteristics of fragile state and post-conflict dynamics is well beyond the scope of this section, whose aim is rather to detect those pivotal issues which are critical for the measurement of business environment in fragile states. In fragile and post-conflict states, the following aspects are pivotal to understand the business environment. First, the role and the strength of formal and informal institutions have to be emphasized. This is important for a number of reasons. Post-conflict countries are in particular need of a comprehensive public effort to recover war damaged infrastructures and to provide a larger amount of public goods, in order to recreate an environment able to convey dispersed resources.

Moreover, institutions can play a major role in creating a more secure, stable and predictable environment. As Stiglitz (2006) stresses, conflict is an extreme form of breakdown of the society. During the transition from war to peace, the socioeconomic, political, formal and informal institutional environment is atypically unpredictable and can be highly unstable. 6 The implications for economic and non-economic incentives to become an entrepreneur are manifold.

As far as private portfolio decisions are concerned, the willingness to make long term investments or irreversible and process dependent investments is particularly low (Alesina et al. 1992; Alesina and Perotti 1993) and private portfolios are made up of a considerably greater amount of liquid assets than in 'normal' conditions. Moreover, as a war economy has been short of investments for a long time, economic agents are prone to mainly invest in easy tradable goods which are likely to offer a high return (Collier and Gunning 1994). Therefore, there is a high risk of adverse selection behaviours by private agents, which can lead to a suboptimal amount of those investments that foster sustainable growth and a more stable environment.

Moreover, conflicts and state fragility offer remarkable possibilities for profits and rents. In this scenario, the role played in a possible relapse into conflict by incumbent or new economic agents cannot be underestimated. As a matter of fact, post-conflict economic recovery implies restructuring the basis of a competitive market as well as the reallocation or the repression of misallocated resources.

Second, the issue of a productive allocation of entrepreneurial resources, which is important in any economic system, acquires a specific relevance in post-conflict dynamics (Naudé 2007).

6 Collier (1994) and Collier and Gunning (1994) identify three kind of insecurities affecting private economic agents in the aftermath of African civil wars: micro level insecurity, '... because civil warfare leaves a legacy of an armed population desensitized to violence' (Collier and Gunning 1994: 11), macro-insecurity, which '... is the fear that the state will be overthrown by insurrection' (Collier 1994: 39) and large fiscal shocks. 
Fragile and post-conflict countries are characterized by the necessity of structural adjustment in terms of the reallocation of resources. The shift from war to a peace economy implies scaling back military spending, which may mean the need to redirect production and, more often, acquisition from external suppliers. The so-called and often overemphasized 'peace dividend', a buzzword in European and US political debate during the post cold-war period, needs to be seen as being closely connected to the overall strength and capability of institutions and to be considered in a long term perspective. The state has to face increased sources of expenditure. In comparison with non-conflict affected situations, the country has less possibility to make use of domestic debt instruments, as private agents are less prone to invest in an uncertain political environment.

Economies in transition from war to peace are characterized by the presence of individuals who have been out of economic processes as they have been exiled, displaced or engaged in military activities. Therefore, during the transition there are possible working or entrepreneurial resources veterans, exiles - that must be productively reallocated, or allocated, in a peace economy.

Another common aspect of post-conflict states is the different role played by women during war time. Even though strictly connected to war context dynamics, a twofold aspect, can be evidenced which is noteworthy in our perspective. On one side, women are, and remain during conflict, definitely vulnerable economic agents (USAID 2007), on the other, war is likely to modify gender relations, affecting the male breadwinner family structure where it exists. In post-conflict dynamics women can acquire importance as economic agents, with possible strong implications for the economic structure. Nevertheless, this shift does not necessarily imply increased economic or political power and can also lead to a more uneven playing field.

The types of barriers which individuals face in fragile states are both harsher and more diversified. As far as the allocation of economic resources is concerned, a crucial aspect to be considered is the individual necessity to adapt to a changing environment, recalibrating knowledge, personal endowments and capabilities. This is important for entrepreneurs and enterprise employees both from a personal and a social point of view.

In our perspective, there are mainly three relevant characteristics of the entrepreneur. First, the Kirznerian (1973, 1979, 1985, 1992 and 2000) alertness and arbitrage of opportunities, which encompass both Schumpeterian creators (Schumpeter 1934) and individuals 'acting entrepreneurially even when they might not be seen as Schumpeterian creators' (Kirzner 2009). Second, the creation and exploitation of opportunities by investments in new knowledge (Acs et al. 2009) as endogenous growth models suggest (Romer 1990; Aghion and Howitt 1992). Third, the Schumpeterian exploitation of existing knowledge, totally or partially unused by incumbent companies, through the transmission of knowledge spillovers (Acs et al. 2009; Audretsch 1995).

The rationale of shaping a business friendly environment, a regulation which does not hamper entrepreneurial culture and is not burdensome to entrepreneurs, is rooted in the very essence of the entrepreneurial function. As Kirzner (2009: 151) highlights:

... it does seem intuitively obvious that alertness can be "switched off" by the conviction that external intervention will confiscate (wholly or in part) whatever one might notice ... public policies that to any degree deaden the excitement inspired by the prospect of pure entrepreneurial profit must surely lower the level of entrepreneurial alertness.

These kinds of policies, i.e. cutting the red tape of a burdensome regulation, granting the rule of law and reducing taxes are, according to Naudé, a 'necessary, but not sufficient condition for development' (Naudé 2007, 2009a and 2009b). Relying more on what Shackle called judgment of possibilities than on a calculation of certainties (Shackle 1982), entrepreneurship can hardly be considered as a by-product (Schramm 2004; Wohlmuth 2004) of a precise set of reforms, especially 
in post-conflict countries. Important literature has recently emphasized the pivotal role played by knowledge and skills in processes of innovation, development and catching up, highlighting how competences are becoming a conditio sine qua non in all economic sectors in a global competitive environment. In the knowledge spillover theory of entrepreneurship, recently introduced by Acs et al. (2009), the role of entrepreneurs in the process of intra-temporal knowledge spillover is investigated. The theory gives precious insights into the microeconomic foundations of the theory of endogenous growth and highlights the endogenous nature of opportunities, regarded by the prevailing entrepreneurship literature as exogenous.

As far as company employees are concerned, the focus on labour market flexibility can lead to underestimating the importance of firm dynamics which are fundamental in the perspective of an entrepreneurial economy (Audretsch and Thurik 2000, 2004; Carree and Thurik 2006; see also Acs et al. 1999; Wennekers and Thurik 1999). The diffusion of diversified competences at different company levels is likely to be undermined by a highly uncertain and fast changing labour market.

Another aspect of particular relevance in post-conflict countries is social mobility, which is important both for conflict and economic dynamics. As Stiglitz (2006) highlights, restricted social mobility is often a cause of civil strife. From an economic point of view, it constrains resource allocation with suboptimal social outcomes. A consequence of conflicts can be a remarkable shrinking of the social mobility of specific groups of the population. The presence of displaced communities and of ethnic or religious minorities being persecuted or segregated by social, political and economic life can have severe economic implications which cannot be underestimated. These dynamics are also likely to modify the equilibrium of the neighbouring countries.

In summary, at least five aspects of the complex process that turns individuals into entrepreneurs have to be considered: entrepreneurial capabilities, knowledge/skills, motivation, social mobility and, of course, economic incentives.

Third, social ties and economic networks need to be rebuilt or created (Stiglitz 2006; Smallbone and Welter 2001). Post-conflict countries are characterized by a fractioned environment, in which social relations and networks among economic agents, both individuals and enterprises, have been abruptly interrupted. Lower cooperation and undermined company networks represent a severe problem as far as innovative and catching up capabilities of developing countries are concerned. The nexus between the process of catching up, policy and institutions has been contentiously approached by literature. Recent research (Fagerberg and Godinho 2005; Fagerberg et al. 2005) stresses that local innovation systems and networks are crucial aspects, in which of importance is the space for institutional and political support. Cooperation among society's members, as Stiglitz (2006) stresses, can be fostered by the legal system and by a system of incentive rewarding cooperation.

Therefore, in fragile and post-conflict states the need to create, recreate and strengthen economic networks is particularly high in order to develop new and fresh economic resources and to consolidate the transition towards a peace economy (Cusmano et al. 2008; Fagerberg and Godinho 2005; Mazzoleni and Nelson 2007; Mytelka 2004; Niosi 2008). The issue is crucial for rent-based economies (Stiglitz 2006). As a matter of fact, in a rent economy incentives to cooperate are low and economic resources are likely to be seen as a fixed amount, with agents playing a zero-sum game. Moreover, the opportunity costs of conflicts are lower than in an investment-based economy. Therefore, company networks and cooperation among enterprises, along with a competitive market structure, represent an important aspect.

The WB has taken into consideration the highly specific characteristics of post-conflict states and their 'atypical need of financial resources and policy advice' (Collier and Hoeffler 2002), as well as the risks of ignoring their peculiar features. Collier and Hoeffler (2002) analyse the effectiveness of 
aid and the priorities for the reform of policies, governance and institutions in post-conflict societies. The study stresses how growth is more sensitive to policy and how social policies should be the key priority, whereas sectoral and macro policies priorities don't substantially differ in postconflict societies from those in other developing countries.

As shown below, DB conceptualization seems to lack awareness of these specificities and fails to understand some pivotal aspects of post-conflict pro-entrepreneurship policies. The following sections deal with the potential relevance and shortcomings of DB to the specific circumstances represented by post-conflict countries, singling out a number of aspects which need to be taken into consideration and eliciting DB theoretical framework from indicator analysis.

\section{The DB indicators}

What are the DB indicators that are most affected by post-conflict dynamics? How and to what extent can fragile states specificities hamper the effectiveness of the indicators? Is DB capable of detecting the inputs of those entrepreneurial resources through which the market process can be set in motion (Kirzner 2009)?

DB measures different kinds of inputs of entrepreneurship development and ranks the countries according to ten dimensions on the premise that an entrepreneurial private sector promotes economic growth and increases opportunities for poor people. Important literature (Audretsch and Thurik 2004; Kauffman Foundation 2007; Naudé 2007, 2009a and 2009b) has recently emphasized the importance of considering and supporting inputs of entrepreneurial economy, rather than only outputs (companies). This statement seems particularly relevant in post-conflict countries, where the legacies of pre-conflict and conflict dynamics may represent an obstacle to a productive allocation of economic resources.

Moreover, fragile states are likely to be short of inputs recognized as conduits of long term entrepreneurial development. Whilst Audretsch and Thurik (2004) and Naudé (2007) stress the fundamental role of knowledge and skills, the Kauffman Foundation (2007) indicates four policy subjects that are crucial to innovative entrepreneurs: ensuring a skilled workforce, reforming healthcare, promoting innovation and limiting overly burdensome regulation and liability litigation. As a matter of fact, DB relies mostly, if not only, on the latter. By analysing DB construction, the indicators adopted, data selection and policy recommendations, it is possible to discriminate between two broad categories of policies: policies aimed at establishing the rule of law - i.e. registering property, protecting investors and enforcing contracts - and policies focused on the elimination of barriers to entrepreneurship - i.e. starting a business, dealing with construction permits, employing workers, getting credit, paying taxes, trading across borders and closing a business. The premise of DB approach is that:

A vibrant private sector - with firms making investments, creating jobs, and improving productivity - promotes growth and expands opportunities for poor people and that in many countries ... entrepreneurial activity remains limited, poverty high, and growth stagnant ... (IBRD and WB 2004: viii).

DB reports are based on the thesis that although macropolicies are unquestionably important, the quality of business regulation is a major determinant of development.

This preliminary statement introduces two key issues on which the DB is constructed: the process through which entrepreneurship enhances social and economic development and the role played by institutions. The following questions are therefore crucial in tracing the DB theoretical framework: what does DB mean by development, how does DB define entrepreneurship, which institutional assets and dynamics does DB consider to enhance processes of entrepreneurial promotion and, 
finally, which institutional assets and dynamics does DB consider favour the pivotal role of entrepreneurship in development?

DB reports omit any explicit definition and lack rigorous analytical answers to all four questions. There are two plausible reasons for this.

First, DB data are meant to be transparent and, therefore, objective. As aforementioned, one of the aims of DB is to 'inform theory, producing new indicators ... facilitating tests of existing theories and contribute to the empirical foundation for new theoretical work on the relation between regulation and development' (IBRD and WB 2004: x). Thus, one of the purposes seems to present empirical evidence on business regulation which justify an ex post adherence to theoretical positions.

Second, a number of key concepts are regarded as unquestionable and automatically interacting with each other. But concepts do matter, both when positive and normative statements are concerned. Different assumptions may lead to different conclusions, determining which aspects of a phenomenon are measured. Lack of clarity on definitions and on assumptions hinders critical analysis of the results presented and the full awareness of the objectives pursued by policy recommendations. ${ }^{7}$

DB adopts a 'one size can fit all' (IBRD and WB 2004) development strategy, which is made up of a number of predefined steps that foster entrepreneurship. The assumption is that improvements in a business environment occur through a precise set of de novo reforms. The one size can fit all perspective, whose failure has been emphasized by important literature (Easterly 2001; Acs et al. 2008), becomes even more dangerous in fragile and post-conflict areas, as discussed below. It is worth noting that DB reports identify different solutions in relation to the stage of development of a country in just two precise cases. The good practice of private inspections in the procedure of issuing building licences (introduced in Finland in 2004) is regarded as unworkable in developing countries. The reason is that in developing countries courts are likely to be less efficient and the risk of revocation of professional licences is likely to be poorly effective in inducing private inspectors to act correctly. As far as closing a business is concerned - while rich countries have developed complex bankruptcy procedures, which need high institutional and administrative capabilities developing countries should focus on less formal methods to enforce payment of the secured debt.

The indicators which analyse policies aimed at establishing the rule of law address crucial aspects of post-conflict dynamics. Macro-insecurity is actually likely to substantially undermine reliance on public services. For example, contested property rights are a legacy of civil wars (Collier 1994). At the same time, regulations which protect investors are likely to help stabilize an uncertain environment, increasing the opportunity costs of not investing. Therefore, the development of indicators such as enforcing contracts, registering properties, protecting investors, as well as getting credit, is useful in addressing some pivotal aspects of those market supporting institutions which need to be reconstructed and strengthened in a conflict affected environment. It is also worth noting that the two exceptions to an approach drastically against public intervention in market processes are related to two of these indicators: in the background paper of the getting credit indicator, the authors stress the importance of public credit registries for the development of credit market institutions in developing countries, highlighting how this can be considered as 'a rare example of an apparently successful state intervention’ (Djankov et al. 2007: 301). Moreover, the background

7 The issue of the neutrality of the data cannot obviously be analysed in this paper, whose objective is simply to highlight the unavoidable implicit theoretical choice at the basis of any empirical research and the risks of mystifications of an excessive emphasis on decontextualized quantitative data. 
paper on protecting investors indicator (Djankov et al. 2008c), 8 is explicitly against a laissez faire approach in the stock market, and stresses the necessity of an active public sector whose pivotal role is to regulate the playing field enforcing private actors as far as both access to information (through extensive disclosure and approval by disinterested shareholders) and power to act (voting and litigation) are concerned. Fines and criminal sanction, on the other hand, seem not to benefit the stock market.

In the following section the more relevant indicators dealing with barriers to entrepreneurship will be considered, namely starting a business, paying taxes, employing workers and dealing with construction permits.

\section{Critical assessment}

\subsection{General assessment}

The assumptions and theoretical statements used to make businesses comparable across countries identify a specific target of DB indicators: a 'vibrant private sector' (IBRD and WB 2004) mainly made up of domestic, small and medium size enterprises regarded as a fundamental engine for growth, employment and development, i.e. entrepreneurial SMEs.

But entrepreneurial function does not acquire a distinct, specific role in DB reports: entrepreneur, manager and owner of an ongoing business are often regarded as synonymous. Even though they often appear to partially overlap in practice, they are nevertheless functionally and theoretically distinct (Baumol 1968). This distinction has both analytical and political implications.

The choice by DB of measuring entrepreneurship by focusing on the number of registered enterprises ${ }^{9}$ partly depends upon the availability of comparable statistical data, but the implications are nevertheless important as far as DB explanatory power is concerned, especially in post-conflict dynamics.

Data concerning business death rates, business churn, net business population growth and survival rates seem pivotal in connecting the act of doing business with an entrepreneurial function and in assessing long term sustainability and development potential of the private sector, along with its potential to influence the welfare and growth of a disrupted country. 10 The issue is taken into consideration by the principal indicators of entrepreneurship, such as the General Entrepreneurship Monitor (GEM), which places particular stress on innovation, and the Kauffman Index of Entrepreneurial Activity (2008). The aim here is not to compare the indexes but rather to outline the possibilities offered by different approaches. The Kauffman Index, for example, relies on the creation of new businesses measuring new US business owners in their first month of significant activity. The approach of the Kauffman Foundation aims at capturing the qualitative aspects of business activity, presenting separate estimates for gender, demographic groups, states, metropolitan statistical areas or sectors of activity.

8 In which an anti-self-dealing index is calculated.

9 See the starting a business indicator methodology and the background paper on the Paying Taxes indicator (Djankov et al. 2008d), in which entrepreneurship is measured by the business density measure (defined as the number of registered establishments per 100 members of the working population) and the business registration measure (defined as the average 2000-4 ratio of business registrations over the number of business establishments).

10 The OECD SME and Entrepreneurship Outlooks and the GEM have developed analysis frameworks which encompass these kind of data, but the concrete availability of this sort of cross-sectional information is quite poor at the moment (see also OECD 2001b, 2003, 2007a, 2007b and 2008). 
Thus two issues arise: the first concerns what DB indicators really measure? Entrepreneurship or business? If the indicators only had descriptive and analytical purposes, the focus would be on correctly presenting the data, which are undoubtedly a unique source of precious information on doing business worldwide. The second issue is based upon the normative approach of DB. On the premise that 'what gets measured gets done' (DB 2005, 2007 and 2008), to clarify what is actually measured acquires a normative value. The problem is acknowledged by the Independent Evaluation Group (IEG), a unit within the WB in charge of the assessment of the International Finance Corporation (IFC) work towards the private sector:

... the DB indicators deal with the part of the regulatory regime that governs the start-up, operation, and growth of businesses ... DB assesses the burden of regulation on firms without aiming to capture the social or economy-wide benefits that regulations yield, such as safety, environmental protection, worker protection, or transparency.11 DB offers a consistent yardstick for comparing countries on regulation as seen from the firm's private point of view. But a complete appreciation of the quality of the business climate must also measure the quality of infrastructure, labour skills, competition policies, and other determinants and outcomes of investment and profitability (IEG 2008: xi).

Yet, the explicit normative function given to the DB since the very beginning seems to sharply contrast with the statement that 'the context and perspective on what DB really measures or addresses are crucial for policy makers and practitioners to keep in mind'(IEG 2008: xi).12

The DB entrepreneur is a standard economic agent. His choices are predictable because they are guided by an individualistic view, according to which the main purposes are to maximize profit and to optimize the choice between regular or irregular economy. The DB approach seems therefore to follow the approach to entrepreneurship of neoclassical microeconomics, which is based upon short run market equilibrium and on standard, rational maximizer agents. According to the mainstream approach, economic agents act in perfectly competitive product markets, in which technology is given and individual workers and entrepreneurs are price takers (Parker 2004).

This perspective fits particularly well the one size can fit all strategy and disregards a number of aspects that are pivotal in research on entrepreneurship. Research on entrepreneurship has not developed a dominant paradigm up to now (Grégoire et al. 2001): in its history it is possible to identify a number of strands, which Landström (2004) links to different economic development stages. At the same time, different strands can be singled out in future development of entrepreneurship research (Corbetta et al. 2004). It is possible to elicit from different conceptions of function and origin of entrepreneurship some common aspects which allow one to discriminate between neoclassical economics on one side, and entrepreneurship research in a stricter sense on the other (Baumol 1968, 1983, 1993, 2004 and 2005; Barreto 1989; Casson 1987, 2003; Kirchhoff 1991; Metcalfe 2004; Parker 2004 and Rosen 1997).

As a case study the DB reports use a domestically owned limited liability company, which operates in the country's most populous city and employs between ten and 50 national employees. The representativeness and comparability of the example chosen varies significantly both in respect to different countries and to different regions within the same country.

11 The DB reports list some methodological limitations to the index. In particular, six areas are considered relevant for business environments which are not measured by DB indicators: proximity to large markets, quality of infrastructure, security, macroeconomic stability, corruption, the labour skill of the population and the underlying strength of institutions (DB 2007 2008, 2009 and 2010).

12 Author's emphasis. 
This choice disregards two fundamental aspects to be considered. Local and regional conditions exert a deep influence on entrepreneurial development; the role played by decentralized policy making is thus crucial. It is also worth noting that a common feature of developing countries is high interregional inequalities in terms of income per capita, labour demand and development of entrepreneurship. Moreover, policy enforcement may be better in the capital city.

The problem has been partly recognized by the DB reports, which state that 'may this choice not be representative of regulatory practices in other parts of the country' (IBRD and WB 2004, 2005, 2006, 2007, 2008 a, b, c, and 2009). Subnational DB analyses for 17 countries have been recently released and, at the time of writing, other five subnational reports are planned or have to be finalized. However, subnational reports consider only few indicators and are not released on a regular basis.

As far as post-conflict dynamics are concerned, the following aspects need to be considered: transaction costs, environmental insecurity and uncertainty, sources and role of innovation, in particular knowledge and skills, and firms’ networks and social mobility.

The theme of security of property is pivotal in the DB approach, of which the Coase theorem seems to be one of the pillars. But, if the reports keep stressing the fundamental role of well-defined property rights in determining efficiency, they tend to disregard the presence of transaction costs. And yet, conflict dynamics remarkably increase transaction costs, bringing about social fragmentation and jeopardizing transactions (Collier 1994). For example, the starting a business indicator only takes into consideration compulsory costs and not the time needed to acquire information, 'the entrepreneur being aware of all entry regulations and their sequence from the beginning' (IBRD and WB 2009). As noted by Arruñada (2007), this approach risks to result in unreliable indicators. 13 Moreover, the assumption of complete and perfect information leads to a biased comparison among conflict and non conflict countries. Yet, the concrete possibility of gathering information dramatically decrease in fragile states and conflict or post-conflict environments. An unstable policy environment that changes often creates an uneven playing field. In such a situation those who have privileged access to information can make strategic choices, while others have to try to develop despite hostile external conditions (Smallbone and Welter 2001).

The indicator, on the one side, lacks any concern about the qualitative characteristics of entrepreneurs and businesses that are created (Smallbone and Welter 2001) and, on the other side, develops an incomplete analysis of the process which leads to start-ups, focusing on a partial consideration of the economic incentives to entrepreneurship.

What prevents an individual becoming an entrepreneur in a post-conflict country can significantly differ from non-conflict affected countries. As Smallbone and Welter (2001) note for transition countries, it is likely, under an unpredictably changing environment, that the aim of individuals is to protect themselves from uncertainties. A defensive more than entrepreneurial attitude, with cash flows utilized for raising general living standards and not for developing enterprise, and the amount of long term and irreversible private investments is likely to be suboptimal if the state does not subsidize investment choices (Collier and Gunning 1994).

The DB approach, moreover, completely disregards the sources and the role of innovation in development processes and seems rather focused on a static and traditional manufacturing economic system. As Fagerberg and Godinho (2005: 521) highlight:

13 Real costs and time differ from data estimated, as the case of US procedure for registering sales tax testifies, see Arruñada (2007). 
... the need to develop a system which is capable of innovating has become more difficult as the progressive technologies have become less 'congruent' with the economic conditions (particularly skill-base and R\&D infrastructure) that prevail in many developing countries.

As far as catching up processes of developing countries are concerned, links with the technology frontier and with markets and supply of needed skills are crucial aspects to consider (Fagerberg and Godinho 2005). In post-conflict countries the problem is likely to be harsher. Policies aimed at fostering personal skills and capabilities are a fundamental part of pro-entrepreneurship strategies, even though the relation between diffusion and commercial exploitation of knowledge is not straightforward, and the learning and creation of knowledge is not measurable (Smith 2005). This is true both for education, which can be evaluated only from a long term perspective, and for economic knowledge.14 As already highlighted by Arrow (1962), knowledge strongly differs from other factors of production. Traditional indicators of innovation, i.e. R\&D expenditures and data on patents, seem to miss the very essence of the issue. On the one hand, as research on innovation has shown, R\&D is not the principle type of expenditure in innovation. Since the seminal work of Rosenberg (1976, 1982) and Kline and Rosenberg (1986) and constantly confirmed by research on innovation, non-R\&D input of innovation (training, design, market exploration, equipment acquisition and tooling-up) is to be considered central in innovation processes (Smith 2005). On the other hand, data on patents tends to capture invention rather than innovation. Precious insights have been given by multi-indicator approaches and by innovation surveys, both focused on technological innovation and firm level innovation activities (OECD 1992, 2001a and 2002). Notwithstanding, these aspects seem unavoidable in assessing post-conflict economic recovery and entrepreneurial promotion.

It seems pivotal to monitor and assess policies aimed at creating and strengthening firms' networks and at increasing information and knowledge sharing, all elements more and more necessary to foster innovation (Mazzoleni and Nelson 2007; Mytelka 2004; Niosi 2008). Moreover, in postconflict areas the environment is highly uncertain and rapidly changing and information is scarce and costly. These conditions make it more difficult than normal to identify reliable suppliers and customers. In the long process of post-war recovery, missing institutions are 'substituted' by long term relations between economic actors, as highlighted by Stiglitz (2006) and shown by McMillan and Woodruff (1999a, 1999b and 2002) in the case of transition countries:

How did the entrepreneurs succeed in overcoming the lack of market supporting institutions? Ongoing relationships among firms substituted for the missing institutions. Firms relied on the logic of the incentives to cooperate that arise in playing a repeated game. (McMillan and Woodruff 2002: 159).

As aforementioned, social mobility acquires in a fractioned environment a particular relevance. Addressing the economic potentialities of women is of major importance. The role of women is remarkably disregarded by DB: despite the declared intention (IBRD and WB 2008) of the development of an indicator measuring opportunities for women, DB 2010 does not address the issue. If included, such an indicator would substantially modify rankings (see for a proposal Hampel-Milagrosa 2008). Also, the DB entrepreneur is assumed to be national, a strong assumption that acquires more relevance in post-conflict dynamics. The role of (ethnic or religious) minority and immigrant entrepreneurs (Naudé 2007) must be analysed. The same can be said for entrepreneurs in diaspora and for return migration; recent literature (McCormick and Wahba 2000;

14 The distinction between economic knowledge and knowledge in a broader sense has been emphasized by Arrow (1962). As Carlsson and Fridh (2002) and Acs et al. (2009) remember, only one to two per cent of the inventions are successfully commercialized and between 10-20 per cent of licences yield significant income. 
Taylor 2006) has considered the role of the latter on the development of skilled entrepreneurship in their country of origin.

DB therefore, fails to stress the variety and the complexity of ways through which governments can influence the productive allocation of entrepreneurship, and does not detect fundamental inputs of entrepreneurial development.

\subsection{Assessment of the starting a business indicator}

Starting a business ranks the countries according to four sub-indicators, the weighted average of which 15 forms the indicator: the number of procedures, time, cost and paid-in minimum capital necessary to start and legally run a business. Fewer procedures, and less time, cost and capital, increase the score a country acquires (Table 1).

The outcomes of easier and faster procedures to starting up a business are, in the DB approach, more start-ups, less informal economy, with consequently more protection of employees and higher productivity caused by increased entry pressure, which in turn leads to more competitiveness between enterprises.

In post-conflict countries start-ups play an important role for a number of reasons. First, as Naudé (2007) highlights, they are likely to have fewer legacies with conflict dynamics. A major task that must be dealt with in post-conflict economic recovery is the necessity to reallocate into peace and productive activities entrepreneurs who have been active during the conflict. The question is, on one side, to convey entrepreneurial resources which need to adapt to a new environment. On the other side, during the first post-conflict period, societies are particularly unstable and the possibility of a relapse into conflict remains extremely high16 (Azam et al. 1994; Collier 2000; 2006; Naude 2007).

The role played by economic agents in this phase cannot be underestimated. A major issue that must be tackled is dealing with those entrepreneurs that have gained economic and political power because of the conflict and therefore represent a force prone to increase instability and social, political and economic fragmentation. Even though the dynamics among forces in a fragile area tend to reproduce themselves, it can be stated that, according to Mcmillan and Woodruff's (2002) analysis of the role of SMEs in transition economies, new SMEs can contribute to create a business environment more conducive to a productive allocation of entrepreneurship.

Second, even though the evidence of a better performance of de novo companies in respect to the private sector as a whole are not uncontroversial (McMillan and Woodruff 2000, 2002 for transition countries), recent literature (Audretsch and Keilbach 2003; Audretsch et al. 2002; 2006) has emphasized the positive effect of start-ups on employment and growth. As outlined above, in postconflict countries there is a necessity to reallocate, or allocate economic agents that have been out of the economic process during the conflict.

Therefore, in this perspective, the DB focus on start-ups seems to properly address a specificity of post-conflict countries. Nevertheless, there are two aspects which need to be considered. First, the question that must be coped with in post-conflict countries is not the lack of entrepreneurial resources, but their productive allocation (Naudé 2007). This issue will be analysed in the next section. Second, procedures for starting up a business are equated to entry barriers which obstruct entrepreneurship and private investment. This statement is drawn from public choice theory on regulation and from the hypothesis that two procedures are 'sufficient for business registration:

\footnotetext{
1525 per cent for each indicator.
}

16 The World Bank estimates 44 per cent possibility within five years. 
notification of existence and tax and social security registration' (IBRD and WB 2004: 17 and 21; IBRD and WB 2005: 19).17 As noted by Arruñada (2007: 2)

... [the] use of this simile [between procedure for starting up a business and entry barriers] leads to omission of the fact that, by incurring certain formalisation costs today, transaction costs in the future will be reduced, whereas conventional entry barriers do not generate this kind of positive effect. 18

The perspective is a company's short term private point of view, mainly considering private costs while the social and long term private benefits of regulation are often disregarded. Regulation of entry is analysed merely from an entrepreneur's perspective, taking into account only quantity and not quality and therefore disregarding the costs borne by other agents, namely public administration and courts (to whom registration formalization provides necessary information) and other companies (due diligence) in the case of poor quality registration services. DB firmly upholds the elimination of minimum capital requirements and reliance on private contracts between creditors and debtors, which would substitute capital rules. This position is in line with an approach that mainly relies on the market as a source of efficiency, besides highlighting an element that supports the efficiency of common law.

The basic hypothesis on which the reports are implicitly built is Baumol's thesis of the fundamental role of institutions in influencing the allocation of entrepreneurship resources. According to this thesis, what varies most among countries is not the number of entrepreneurs or 'the nature of their objectives', but the relative pay-offs society offers (Baumol 1990) to entrepreneurial activities. It is therefore possible and desirable to modify the reward structure in the economic system in order to enhance a productive allocation of entrepreneurial resources. So, what is the role of regulation in a DB perspective? The background study (Djankov et al. 2002) on which the starting a business indicator is methodologically and theoretically based, in accordance with de Soto's work (De Soto 2000; De Soto et al. 1986), provides evidence19 that:

... the countries with more open access to political power, greater constraints on the executive, and greater political rights have less burdensome regulation of entry ... than do the countries with less representative, less limited, and less free governments (Djankov et al. 2002: 5).

This statement is presented as an ex post and evidence-based adherence to public choice theory. Entry regulation is set up in order to benefit regulators, who seek to gain rents exerting unjustified control on private entrepreneurs, according to the toolbooth strand of public choice theory developed by de Soto et al. (1986) and de Soto (2000), McChesney (1987), Shleifer and Vishny (1993, 1998). No efficiency or public interest reasons justify the majority of entry regulations, no

17 It is worth noting that the DB reports consider environmental permits, statistical and health benefits registrations as socially desirable practices (IBRD and WB 2004: 21). In DB approach, any other procedure for starting up a business not only can limit competition, but has also dubious purposes and negative social outcomes, preventing 'people from getting out of poverty' (IBRD and WB 2008a: 9).

18 Arruñada (2007) comments the negative consequences of the reforms undertaken in El Salvador, Spain, Colombia, Afghanistan and praised by DB reports (DB 2005, 2007). See also Bath (2007), Blanchet (2006), du Marais (2006) and du Marais et al. (2006).

19 The empirical research is based on a dataset describing the regulation of entry by start-up companies in 85 countries in 1999. The analysis takes the number of procedures, the official time and cost into consideration. 
empirical evidence support Pigou's public interest theory of regulation in the pilot research carried out by the groups of researchers headed by Simeon Djankov.20

From our standpoint, two aspects are relevant here: on the one side, the role played by the state in resetting the rules of the game, in coordinating different economic actors, in facilitating economic exchanges and development, is substantially undervalued. On the other, the 'manichean' view (Arruñada 2007) which supports the entire DB theoretical framework represents the influence between business environment and entrepreneurial behaviour as a uni-directional relationship between two homogeneous parties, preventing DB from investigating more complex dynamics. The relationship between 'the institutions of the market place and the spectrum of entrepreneurial behaviour it engenders and supports' (Metcalfe 2004: 35) is widely recognized, both politically and academically. However, it is important to take into account the influence that a particular social and cultural milieu, in which entrepreneurship behaviour develops, may exert on political and institutional processes. Moreover, the dualistic vision of institution and politics on one side and entrepreneurs on the other, does not take into account the spectrum of the heterogeneous forces involved. The response to the regulation of economic agents varies widely and does not often confirm the simplistic dualism regulation versus the free market. This holds particularly true as far as post-conflict dynamics are concerned. Moreover, the serious need for public intervention requires an assessment of government level of corruption, effectiveness, capability to define a long term strategy, all aspects disregarded by DB conceptualization, representing public intervention per se as a shortcoming in the economic system.

\subsection{Assessment of the paying taxes indicator}

The indicator paying taxes measures amount, procedural and time requirements of taxes and government mandatory contributions 21 a SME is required to pay in a fiscal year. The indicator is made up of three indicators: tax payments for a manufacturing company, time required to comply with three major taxes and total tax rate.

The rationale of the indicator is that corporate taxes and social and labour contributions lessen the economic incentives to engage in an entrepreneurial venture, having consequently negative effects on aggregate investments, FDI and entrepreneurship activities and leading to slower economic growth, more reliance on debt than on equity 22 and more irregular economy. In the DB analysis, burdensome regulation causes economic agents to give up their economic activities regularly carried out (or even not to engage in a regular economic activity) and force them to choose the unregulated alternative, which DB reports define an informal economy and estimate as the percentage of activity that is unofficial or not registered (Djankov et al. 2008d). The concept of informal economy in the DB reports seems to identify economic activities carried out against the rules posed by a system - i.e. irregular economy (Dallago 1990) - not activity of self-consumption, criminal activity or simply unrecorded activity. Thus it is worth noting that the method of calculation chosen overlaps two conceptually and logically distinct phenomena, and that the reports

20 Three studies by Djankov, Ganser, McLiesh; seven studies by Ramalho and Shleifer, four studies by Hart and La Porta, four studies by Lopez-de-Silanes, Freund, Pham and Botero (see also Djankov et al. 2002, 2003, 2007, 2008a, 2008b, 2008c and 2008d)

21 The profit or corporate income tax, social contributions and labour taxes paid by the employer, property taxes, property transfer taxes, dividend tax, capital gain tax, financial transaction tax, waste collection taxes and vehicle and road taxes.

22 These statements are presented as the results of the empirical research the basis of the paying taxes indicator (Djankov et al. 2007). The data are on 85 countries. 
do not clarify their definition of informal economy, a controversial concept which encompasses a number of different actors and aspects.

Several caveats are necessary as far as post-conflict countries are concerned. Collier (1994) highlights the decay of institutions and conventions of civil society - the private sector has learned how to evade the state - and, consequently, the inadequacy of the state to effectively manage the tax-gathering system and to increase revenue without intensifying arbitrary actions. Moreover, the author states the necessity of setting low taxation on transactions in order to help the market recover. Nevertheless, returning to market implies a comprehensive effort aimed at restructuring the fundamental institutions, the formal and informal rules of the game, which can hardly be done by the interaction of private economic agents. A trade-off comes, in this perspective, between low taxes and a government budget capable of restoring and activating virtuous market mechanisms.

The DB approach conceives of underdevelopment as being the result of private underutilized social and economic potential, as a waste of opportunity due to institutional frameworks which inhibit economic agents. The roadmap to development therefore means freeing the private sector from bureaucratic and political ties which hinder growth.

Even though certainly 'setting up and developing businesses results from the creativity, drive and commitment of individuals rather than as a result of government action' (Smallbone and Welter 2001: 259), the role of public intervention in post-conflict dynamics seems pivotal for at least four reasons, which represent increased sources of public expenditure. First, there is room for substantial state intervention to help war damaged infrastructures recover, which is necessary to foster market processes (Anand 2009). As a matter of fact, these kinds of public interventions can have a rapid and positive influence on the indicator trading across borders, which records procedural requirements for exporting and importing goods by ocean transport. Second, the state needs to ensure security in an environment where micro-insecurity is considerably high. Post-conflict dynamics exert a remarkable influence on individuals' portfolio choices, which, as mentioned above, are more liquid than normal, and on entrepreneurs, who are likely to prefer reversible and short term investments. Therefore, lower taxes, which decrease government budgets, are likely to produce more individual savings rather than foster private investments. Thus, public interventions which lessen micro-instability and ease market exchange are important. Third, the role of the state as a facilitator of knowledge creation and sharing, investments and spillovers seems pivotal. Research that sustains the effects of policy - specifically corporate-income tax rates, minimum wages and bankruptcy law - on entrepreneurship across the US has been presented (Garrett and Wall 2006). Nevertheless, what Schramm (2004) stresses is the necessity of taking into account the whole system that supports entrepreneurship. The author presents the US system as being characterized by a number of correlated aspects that along with favourable business policies and regulations, encompasses both the role of universities which are strongly engaged in research and firmly linked with enterprises, and the fundamental role of the government in funding programmes and research in firms and universities.

There are many conduits to entrepreneurial development which post-conflict countries are likely to be particularly short of: investments in $R \& D$, the general level of knowledge, networks and relations among firms, high skilled employees who can detect and exploit opportunities and social services, which can support and sustain entrepreneurial ventures by reducing the individuals' exposure to social risks. At the same time, post-conflict countries can be unusually respondent, with unexploited human resources and capabilities which can be very productively harnessed. Therefore, what seems necessary for private sector development are broadly-based institutional interventions:

... aimed at supplying common goods such as training, technological capabilities and quality assurance ... There is the need for regulative interventions encouraging 
larger local and foreign enterprises to adopt more socially inclusive patterns of sourcing and subcontracting (Schulpen and Gibbon 2002: 6, for sub-Saharan Africa).

Finally, the redistributive role of the state seems to be important in the phase of transition. Market disruption brings about a less competitive environment in which profit margins widen and there are more opportunities for rent positions; at the same time, opportunities for profits and rents, which would have been illegitimate in a non-conflict situation, arise (Collier 1994; Collier and Gunning 1994; Keen 1994). Thus, post-conflict societies are likely to be characterized by high income inequality and weak social protection. Two consequences are relevant here: first, high income inequality increases vulnerability and internal conflicts, and makes difficult the restoration of normal conditions. Second, higher income inequality implies a market characterized by weaker demand and lower individual capability to engage in entrepreneurial ventures.

Another element which is worth noting about the paying taxes indicator is that social contribution and labour taxes are encompassed in order to measure all 'imposed charges that affect business accounts' (IBRD and WB 2009). The construction of the indicator is in line with the DB approach towards the dynamics between entrepreneurs and workers, focusing on two desired policy outcomes: increasing flexibility of labour regulation and decreasing costs. The implication of the DB perspective will be discussed in the next section.

\subsection{Assessment of the employing workers indicator}

The indicator measures the regulation of employment, specifically how it affects the hiring and firing of workers and the rigidity of working hours (IBRD and WB 2009), and is made up of five sub-indicators: difficulty of hiring, rigidity of hours, difficulty of firing, rigidity of employment and firing cost (Table 2).

In the background paper of the indicator, Botero et al. (2004) present the results of a comparative empirical study on regulation of the labour market (employment, collective relations and social security laws) in 85 countries. The paper shows how higher regulation is associated with higher levels of unemployment and a larger irregular economy, and is therefore harsher on the weaker part of the work force, i.e. women and young people, and thus causes a de facto weakening of the system of social protection. 23 The risk is to increase unemployment and to force individuals towards an irregular economy whilst trying to protect workers and regulate employment. If, in the DB vision, public institutions often fail, reliance on the market leads to efficiency even in the labour market: DB report 2004 states that if business does not provide its workers with adequate conditions of employment, other companies will attract the workers'(IBRD and WB 2004: 93). DB therefore adopts a neoclassical approach to the labour market, in which real wages determine equilibrium, similar to what happens in any other market.24 DB 2009 highlights how overly rigid labour regulation brings about difficulties in adjusting to demand, limits firm size and discourages both incumbent and possible entrepreneurship, increasing firm costs and decreasing economic incentives to become an entrepreneur.

From our standpoint, the following remarks are necessary. Positive externalities of labour market regulation and of a well-funded social security system are disregarded: minimum wages, restriction of working hours, employment protection and restriction on the use of fixed term contracts are considered barriers and sources of delay for business, in spite of the wide and controversial

23 Moreover Bertola tests the reliability of the indicators and the empirical findings of Botero et al. (2004) and concludes that the evidence presented is 'rough, far from clearcut' and supporting 'simplicistic views of labour market institutions' (Bertola 2005).

24 See Lunghini et al. (2001) for a critical analysis to neoclassical approach to labour market. 
empirical and theoretical debate on these issues (see Becker 1964; Berg and Cazes 2007; Card and Krueger 1995; Eyraut and Saget 2005; Fox 2006; Lee and McCann 2007; Neri et al. 2001; Williamson 1995). The less a country regulates, the better the score the indicator assigns. Criticisms have been made that it is possible to change a DB ranking without improving business (Channel 2008). Moreover, empirical research on labour market has shown that it is possible to improve the DB ranking but making, at the same time, business and quality of life worse. 25 It seems relevant what DB 2008 highlights that 'it is now possible26 for an economy to receive the highest score on the ease of employing workers - indicating the most flexible labour regulation - and comply with all 187 ILO conventions' (IBRD and WB 2008b). For the first time DB 2009 recognizes the necessity of a good balance between worker protection and labour market flexibility and lists the countries that have ratified the four ILO conventions which are considered relevant for the indicator. This aspect, in any case, is not included in the assessment of the policy of a country. Consequently, not only does DB not value the compliance with ILO regulations, but also it does not establish any minimum regulation standards to meet.

The indicator does not consider any interaction between regulation in different areas. For example, flexibility in labour market and taxes to finance passive and active labour market policies, are necessarily connected in flexicurity systems, which are 'economically and socially superior to flexibility systems' (Auer 2007; see also Berg and Cazes 2007). Moreover, by stating that 'Denmark, Hong Kong (China), New Zealand, Sweden, and the United States are among the countries with the most flexible labour regulation overall' (IBRD and WB 2004: 83), the DB report completely decontextualises labour regulations from the overall institutional and political framework of a country, disregarding how dramatically welfare systems vary among the countries quoted.

A further shortcoming of the indicator is the narrow focus on flexibility of the labour force. Critical for an entrepreneurial economy is the quality of the workers: the Kauffman Foundation (2007: 2) stresses that 'entrepreneurs tell us that perhaps the most significant constraint on their future growth, and on the growth of future entrepreneurs, is the difficulty finding and attracting 'talent' highly skilled, entrepreneurial workers'. In post-conflict dynamics, the above mentioned aspect is critically intertwined with the necessity to resettle displaced working forces and to recreate an environment conducive to entrepreneurial development. It is worth noting that civil war creates an exodus of the most skilled human capital (Collier 1994), displaced communities need to be reintegrated and to find income-earning opportunities, while demobilized soldiers are likely to be unemployed. Notwithstanding the context specific nature of the situation, it is also plausible to hypothesize a substantial number of demobilized soldiers who are unskilled, or at least poorlyskilled outside the military sphere (Collier 1994 for the cases of Uganda and Ethiopia) and seriously needing to adapt their competences to a new environment.

The position of working women in a post-conflict environment acquires particular aspects to consider. During conflicts, women are likely to have been widely employed in order to sustain the war economy. It must also be considered that a substantial number of families are likely to rely on working women in a post-conflict period. Given that an economy has to be shifted into peaceful activity, that women are typically vulnerable economic agents and that social services are likely to be weak in post-conflict countries, it is very necessary to assess the relative position of women in a labour market and their possibility of being productively reallocated.

25 See the cases of Argentina and Bulgaria analysed in Berg and Cazes (2007).

26 Author's emphasis. 
This remark leads us to consider the assumptions of the indicator: the worker is a full time, 42 year old, non-executive and male employee with 20 years of tenure in the same firm; he is a lawful citizen, of the same race and religion of the majority of the country's population and is not a member of a labour union, unless membership is mandatory (on the representativeness of this case study, see Berg and Cazes 2007). Particularly in this case, comparability and simplification risk disregarding crucial aspects in addressing and coping with social and economic development, not only, but especially, in post-conflict dynamics. DB does not deal with phenomena whose aftermaths are dramatic not only in social and legal but also economic terms. Ethnic and religious segregation, exodus, return migrations and the connected possible increase in working and entrepreneurial skills are all aspects which are not possible to disregard in tackling processes of entrepreneurial development in fragile states (Naudé 2007).

Finally, the possible trade-off between a highly flexible labour market and the development of workers skills and competencies (Antonelli 2009) is disregarded not only by the indicator here considered but also by the academic literature. The relevance of this trade-off seems particularly severe in a fragmented environment in which the reconstruction of social and labour ties and the strengthening of individual skills is pivotal.

\subsection{Assessment of the dealing with construction permits indicator}

DB policy recommendations on dealing with construction permits - named dealing with licenses until DB report 2007 - focus on simplification of procedures, limitation of regulators' rent-seeking and corruption, and on efficiency. The recommendations are: to give builders a step-by-step specific chart and do not mandate use of specific materials (IBRD and WB 2006), discard obsolete licensing regulations every decade (IBRD and WB 2007), make information easily available, introduce online licence applications and consolidate project clearances (IBRD and WB 2006, 2008), reduce licensing requirements and 'curb27 inspections' (IBRD and WB 2008), update zoning maps periodically (IBRD and WB 2006), adjust licenses and inspections to the size and nature of the project and involve the private sector (IBRD and WB 2007). The greater the amount of the licences issued, the cheaper and faster the procedures, and the better the score. The necessity of cutting the red tape of a burdensome administration represents a goal worth pursuing. But the risks of prioritizing policy reforms in accordance with this maxim are serious. From this perspective regulation of licensing, as well as labour regulation, being a barrier to business, is seen as a source of costs, delays and rigidity. The problem that DB perspective brings about is twofold: first, the automatic connection between less regulation of business and development is presented as evidence-based and therefore often regarded as unquestionable; second, DB does not establish minimum regulation standards to meet.

DB analyses procedures, time and cost of building a warehouse. The choice seems peculiar. The explicit rationale of this choice seems even more peculiar:

... because warehouse do not house people, there are fewer safety concerns than with construction of offices and homes. At worst, a company's goods could be destroyed by fire, collapse or flooding. What would it take to build such a warehouse legally? (IBRD and WB 2006: 15).

The case study adopted leads to avoiding valuing any security, health or environmental regulation, omitting to deal with pivotal features of the phenomena analysed and compromising seriously the analysis. A common remark is that DB is likely to be beset by poor understanding, which can lead

27 It is worth noting the linguistic choice: in DB 2006 the same recommendation was 'introduce risk-based inspection', a much more neutral expression. 
to misuse (Arndt and Oman 2006; Bakvis 2006; Channel 2008). The remark seems to miss the point, ignoring that the ranking system and the normative approach de facto tends to undermine the role of regulation in areas as security, health and environmental protection. The recommendation of 'don't mandate use of specific materials' (IBRD and WB 2006) in order to avoid the problem of not up-to-date buildings codes, seems here particularly relevant. Recent important literature (Kuesel et al. 2008) has highlighted the critical role of environmental concern in social and economic development. Moreover, building licences should vary according to the features and historical value of the building or the town.

As previously mentioned, the DB theoretical premise and Baumol's theory on the supply of entrepreneurship converge regarding the crucial role played by institutions and policy in favouring entrepreneurship. They instead greatly diverge on the issue of the nature of entrepreneurship. The reports rely on the implicit hypothesis of an automatic positive relationship between what is defined as a better business environment and development. The question is therefore not addressed at all, taking for granted the productive function of entrepreneurship in society. On the contrary, Baumol's central message is that 'the exercise of entrepreneurship can sometimes be unproductive or even destructive' (Baumol 1990: 898-9), and that the role of the rules of the game in the economic system is to induce a productive allocation of entrepreneurial resources. Therefore entrepreneurship can be productive, innovative, with a positive economic and social role or rent-seeking, parasitic or criminal. This statement has important policy implications: supporting existing SMEs does not necessarily imply supporting productive entrepreneurship, and adopting the point of view of the entrepreneur does not necessarily imply assuming a socially and economically sustainable perspective.

As already mentioned, this statement is pivotal in addressing post-conflict strategies aimed at fostering productive entrepreneurship. As Cooper (2006) notes, economic war systems often do not reflect a specific and alternative system of profit, being rather deeply rooted both in pre- and postconflict economic structures. The DB premise, on the contrary, leads to disregarding quality and allocation of the entrepreneurial resources, giving fuel to a one size can fit all strategy (IBRD and WB 2004) based upon a quantitative approach: there is a precise set of policies which exert a positive effect on the business environment and on the society as a whole and that can easily be applied to different contexts. The response of the recipients are predictable and evidence-based. The analysis depicts a sort of trickle down effect which leads from a more business friendly environment to development. As a result, DB policy recommendations often end in a focus on short term horizons and on the relative ease in implementing the reforms. The statement at the basis of this position is outlined in one of the background papers (Djankov et al. 2008d: 25): 'not only deep historical, institutional, and geographical factors, but also policies that can be altered without enormous difficulty' exert a deep influence in economic development. From this perspective, regulation of licences and labour, being a barrier to business, is seen as a source of costs, delays and rigidity.

The precise roadmap depicted, the short term horizons adopted and the normative approach, all lead DB to focus on a standardization, simplification and speed of reforms in a sort of race in which the country which reforms the most gets the higher score. The Reforms Simulator on the DB website, which show how a country's ranking would change if it reformed, and the agonistic terminology often employed in DB reports (see, for example, WB and IFC 2008) are interesting examples of this approach. The focus is therefore on reforms considered easy to implement in different contexts. This approach is also reflected by the methodology of the construction of the indicator (WB and IFC 2008, 2009). Following the logic of 'what gets measured gets done' (IBRD and WB 2005, 
2007 and 2008), DB emphasises the number rather than the quality of the reforms undertaken, with the risk of decontextualized policy recommendation.28

The perspective adopted seems unable to cope with the problems and needs of a post-conflict environment: strong commitment in reconstruction of war damaged buildings and infrastructures (Anand 2009), presence of an uneven playing field, having the market become less competitive during war time (Collier 1994), and the necessity of a comprehensive effort of town and infrastructure planning.

\section{Concluding remarks}

The analysis carried out in the paper identifies three pivotal aspects of entrepreneurship development which need to be considered in fragile and post-conflict states and which are disregarded by DB indicators.

First, the ambiguous and ubiquitous role of entrepreneurship, which is neither positive nor negative in essence. Second, the complex and intertwined legacies between pre-conflict, conflict and postconflict economic systems. Third, the consequently central role played by incentives in economic systems, which cannot be reduced to lessen regulation and room for public intervention.

DB indicators represent a precious source of information, testified by the widespread diffusion of DB reports and by the influence they exert in the political arena. In an assessment of DB pros and cons it seems necessary to discriminate between the positive and normative functions of the indicators, because the problems that arise and the policy implications are different.

As far as the descriptive power of DB is concerned, two kinds of problems have arisen in the paper. The first question is about what the indicators are really measuring. The DB reports, as well as the background papers on which the indicators are constructed, lack definition of the phenomena analysed. The concepts of entrepreneurship and development implicitly assumed in the reports have been analysed, highlighting to what extent the measures chosen can hinder the explanatory power of the indicators, failing in addressing the multifaceted process through which individuals become entrepreneurs, especially in post-conflict areas.

A second issue concerns the short term, private perspective adopted by the indicators. On the one hand, the indicators seem to measure aspects of business environment often linked to a short term view of the business activity, disregarding a more sustainable perspective. The relationships between enterprises, both inter and intrasectoral, and the characteristics of workers are not considered. This approach disregards the sources and the role of innovation, which is the essence of an entrepreneurial economy. On the other, the risks of adopting only a private perspective are serious. Private and social benefits do not always converge and a multifaceted and more comprehensive view is extremely important in public policy analysis, design and implementation.

The perspective of the entrepreneur, which is crucial in the analysis, and the role of public institution are neither mutually exclusive nor incompatible.

However, the main problem with the DB indicators seems to be rooted in their explicit normative power. This aspect is particularly important as far as post-conflict countries are concerned. DB indicators draw a path that is not always consistent with the purpose they declare, disregarding context-specific variables which are critical in the process of reconstruction and development.

28 For example, the poor results in the case of formalization of real estate property in Peru, analysed in Morris Guerinoni (2004). See the analysis presented in Arruñada (2007). 


\section{References}

Acs, Z. J., P. Braunerhjelm, D. B. Audretsch and B. Carlsson (2009). 'The Knowledge Spillover Theory of Entrepreneurship', Small Business Economics, 32: 15-30.

Acs, Z. J., B. Carlsson and C. Karlsson (1999). 'The Linkages among Entrepreneurship, SMEs and the Macroeconomy', in Z. J. Acs, B. Carlsson and C. Karlsson (eds), Entrepreneurship, Small and Medium Sized Enterprises and the Macroeconomy, Cambridge: Cambridge University Press.

Acs, Z. J., S. Desai and J. Hessel (2008). 'Entrepreneurship, Economic Development and Institutions’, Small Business Economics, 31: 219-34.

Addison, T. and T. Brück (2009) 'The Multi-Dimensional Challenge of Mass Violent Conflict' in T. Addison and T. Brück (eds), Making Peace Work. The Challenge of Social and Economic Reconstruction, Basingstoke: Palgrave Macmillan for UNU-WIDER.

Aghion, P. and P. Howitt (1992). 'A Model of Growth Through Creative Destruction', Econometrica, 60: 323-51.

Alesina, A., S. Ozler, N. Roubini and P. Swagel (1992). 'Political Instability and Economic Growth', Working Paper 4173, Washington, DC: NBER.

Alesina, A. and R. Perotti (1993). 'Income Distribution, Political Instability and Investment', Mimeo, Cambridge, MA: Harvard University, Department of Government.

Anand, P. B. (2009) 'Infrastructure Development in Post-Conflict Reconstruction' in T. Addison and T. Brück (eds), Making Peace Work. The Challenge of Social and Economic Reconstruction, Basingstoke: Palgrave Macmillan for UNU-WIDER.

Antonelli, G. (2009). 'Emerging Powers: The New Socio-Economic Scenario', keynote speech at the MIUR - PRIN 2007 and Openlock Project Workshop on 'Globalization, Local Development and Emerging Powers. The Role of Innovation Policies’, University of Bologna, Italy, 6-7 February.

Arndt, C. and C. Oman (2006). Uses and Abuses of Governance Indicators, Paris: OECD Development Centre Studies.

Arrow, K. (1962). 'Economic Welfare and the Allocation of Resources for Inventions', in R. Nelson (ed.), The Rate and Direction of Inventive Activity, Princeton, NJ: University Press and NBER.

Arruñada, B. (2007). 'Pitfalls to Avoid when Measuring Institutions: Is Doing Business Damaging Business?', Journal of Comparative Economics, 35: 729-47.

Audretsch, D. B. (1995). Innovation and Industry Evolution, Cambridge, MA: MIT Press.

— (2006). Entrepreneurship, Innovation and Economic Growth, Cheltenham: Edward Elgar.

Audretsch, D. B. and M. Keilbach (2003). 'Entrepreneurship Capital and Economic Growth', Research Paper 5, available at www.dur.ac.uk/resources/dbs/businessschool/research paper 005.pdf, date accessed 7 February 2010.

Audretsch D. B., M. Keilbach and E. Lehmann (2006). Entrepreneurship and Economic Growth, Oxford: Oxford University Press.

Audretsch, D. B. and R. Thurik (2000). 'Capitalism and Democracy in the 21st Century: from the Managed to the Entrepreneurial Economy’, Journal of Evolutionary Economics, 10: 17-34. 
- (2004). 'A Model for Entrepreneurial Economy', Discussion Paper on Entrepreneurship, Growth and Public Policy, Jena: Max Planck Institute.

Audretsch, D. B., R. Thurik, I. Verheul and A. R. M. Wennekers (eds) (2002). Entrepreneurship: Determinants and Policy in a European-US Comparison, Boston, MA and Dordrecht: Kluwer Academic Publishers.

Auer, P. (2007). From Job Security to Labour Market Security: Flexi-Curity for Reducing Labour Market Segmentation?, Geneva: ILO.

Azam, J.-P., D. Bevan, P. Collier, S. Dercon, S. Gzennixg and S. Pradhan (1994). 'Some Economic Consequences of the Transition from Civil War to Peace', Policy Research Working Paper 1392, Washington, DC: World Bank.

Bakvis, P. (2006). 'How the World Bank \& IMF Use the Doing Business Report to Promote Labour Market Deregulation in Developing Countries', ICFTU/Global Union publications, available at www.icftu.org, date accessed 7 February 2010.

Barreto, H. (1989). The Entrepreneur in Microeconomic Theory: Disappearance and Explanation, Milton Park: Routledge.

Bath, V. (2007). 'The World Bank Doing Business Reports - Regulation and Change in China and Australia’, Research Paper 07/79, Sydney: Sydney Law School.

Baumol, W. J. (1968). 'Entrepreneurship in Economic Theory', American Economic Review, 58: 64-71.

(1983). 'Towards Operational Models of Entrepreneurship', in J. Ronen (ed.), Entrepreneurship, Lexington, MA: Lexington Books.

_ (1990). 'Entrepreneurship: Productive, Unproductive, and Destructive', Journal of Political Economy, 98 (5): 893-921.

(1993). Entrepreneurship, Management, and the Structure of Payoffs, Cambridge, MA: MIT Press.

— (2004). 'Entrepreneurial Enterprises, Large Established Firms and Other Components of the Free-Market Growth Machine, Small Business Economics, 23: 9-21.

- (2005). The Free-Market Innovation Machine: Analyzing the Growth Miracle of Capitalism, Princeton, NJ: Princeton University Press.

- (2009). 'Entrepreneurship, Competition and World Trade' in D. B. Audretsch, R. Litan and R. Strom (eds), Entrepreneurship and Openness. Theory and Evidence, Cheltenham: The Ewing Marion Kauffman Foundation.

Becker, G. (1964). Human Capital: A Theoretical and Empirical Analysis, with Special Reference to Education, New York: Columbia University Press.

Berg, J. and S. Cazes (2007). 'The Doing Business Indicators: Measurement Issues and Political Implications’, Economic and Labour Market Paper 2007/6, Geneva: ILO.

Bertola, G. (2005). 'Distribution, Efficiency and Labour Market Regulation: in Theory, in OECD Countries and in Latin America', in J. Restrepo and A. Tokman (eds), Labour Markets and Institutions, Santiago: Central Bank of Chile. 
Binzel, C. and T. Brück (2007). 'Analyzing Conflict and Fragility at the Micro-Level', paper presented at the UNU-WIDER Conference on Fragile States-Fragile Groups, Helsinki, 15-16 June.

Blanchet, D. (2006). 'Exploratory Analysis of the Indicators Proposed by Doing Business Reports 2005 and 2006 of the World Bank', Working Paper AED-EAL-2006-3, Paris: National Institute for Statistics and Economic Studies.

Botero, J., S. Djankov, R. La Porta, F. Lopez-de-Silanes and A. Shleifer (2004). 'The Regulation of Labour', available at www.doingbusiness.org/documents/labor_June04.pdf, date accessed 7 February 2010.

Bruton, G. D., D. Ahlstrom and K. Obloj (2008). 'Entrepreneurship in Emerging Economies: where are we Today and Where Should the Research Go in the Future, Entrepreneurship. Theory and Practice, 32 (1): 1-14.

Card, D. and A. B. Krueger (1995). Myth and Measurement: the New Economics of the Minimum Wage, Princeton: Princeton University Press.

Carree, M. and R. Thurik (2006). Entrepreneurship and Economic Growth, Cheltenham: Edward Elgar.

Carlsson, B. and A. C. Fridh (2002). 'Technology Transfer in United States Universities: A Survey and Statistical Analysis’, Journal of Evolutionary Economics, 12: 199-232.

Casson, M. (1987). Entrepreneur in J. Eatwell, M. Murray and P. Newman (eds), The New Palgrave. A Dictionary of Economics, Basingstoke: Palgrave Macmillan.

— (2003). The Entrepreneur: An Economic Theory, Cheltenham: Edward Elgar.

Channel, W. (2008). Uses and Abuses of Doing Business Indicators, available at www.businessenvironment.org/dyn/be/docs/149/Channell.pdf, date accessed 7 February 2010.

Collier, P. (1994). 'Demobilization and Insecurity. A Study in the Economics of the Transition from War to Peace', in J.-P. Azam, D. Bevan, P. Collier, S. Dercon, S. Gzennixg and S. Pradhan (eds), Some Economic Consequences of the Transition from Civil War to Peace, Policy Research Working Paper 1392, Washington, DC: World Bank.

— (2000). 'Economic Causes of Civil Conflict and their Implications for Policy', Development Research Group, Washington, DC: World Bank.

- (2006). 'Economic Causes of Civil Conflict and their Implications for Policy', Mimeo, Oxford: Oxford University.

Collier, P. and J. W. Gunning (1994). 'War, Peace and Private Portfolios', in J.-P. Azam, D. Bevan, P. Collier, S. Dercon, S. Gzennixg and S. Pradhan (eds), 'Some Economic Consequences of the Transition from Civil War to Peace’, Policy Research Working Paper 1392, Washington, DC: World Bank.

Collier, P. and A. Hoeffler (2002). 'Aid, Policy and Growth in Post-Conflict Societies', Policy Research Working Paper 2902, Washington, DC: World Bank.

Cooper, N. (2006). 'Peaceful Warriors and Warring Peacemakers', The Economics of Peace and Security Journal, 1: 19-23. 
Corbetta, G., M. Huse and D. Ravasi (2004). 'Crossroads of Entrepreneurship Research: An Introduction', in G. Corbetta, M. Huse and D. Ravasi (eds), Crossroads of Entrepreneurship, Boston, New York, Dordrecht: Kluwer Academic Publishers.

Cusmano, L., A. Morrison and R. Rabellotti (2008). 'Catching up and Sectoral Systems of Innovation: A Comparative Study on the Wine Sector in Chile, Italy and South Africa', Working Paper 48299, Walla Walla, WA: American Association of Wine Economists.

Dallago, B. (1990). The Irregular Economy: the Underground Economy and the Black Labour Market, Dartmouth: Aldershot.

De Soto (2000). The Mystery of Capital: Why Capitalism Triumphs in the West and Fails Everywhere Else, New York: Basic Books.

De Soto, H., E. Ghersi and M. Ghibellini (1986). El Otro Sendero. La Revolución Informal, Lima: Editorial El Barranco.

Djankov, S., C. Freund and C. S. Pham (2008a). 'Trading on Time', available at www.doingbusiness.org/Documents/TradingOnTime_APR08.pdf, date accessed 7 February 2010.

Djankov, S., T. Ganser, C. McLiesh, R. Ramalho and A. Shleifer (2008d). 'The Effect of Corporate Taxes on Investment and Entrepreneurship’, Draft paper, date accessed 15 March 2009.

Djankov, S., O. Hart, C. McLiesh and A. Shleifer (2008b). 'Debt Enforcement Around the World', Journal of Political Economy, 116(6): 1105-49.

Djankov, S., R. La Porta, F. Lopez-de-Silanes and A. Shleifer (2002). 'The Regulation of Entry’, in Quarterly Journal of Economic, 67: 1-37.

— (2003). 'Courts', available at www.doingbusiness.org/documents/LexPaperAug211.pdf, date accessed 7 February 2010.

- (2008c). 'The Law and Economics of Self-Dealing', Journal of Financial Economics, 88: 430-65.

Djankov, S., C. McLiesh and A. Shleifer (2007). 'Private Credit in 129 Countries', Journal of Financial Economics, 84: 299-329.

du Marais, B. (2006). 'Methodological Limits of “Doing Business” Reports', Working Paper AED2006-1, Paris: National Institute for Statistics and Economic Studies.

du Marais, B., D. Blanchet and A. Dorbec (2006). Des Indicateurs pour Mesurer le Droit ? Les Limites Méthodologiques des Rapports Doing Business, Paris: La documentation Française.

Easterly, W. (2001). 'The Lost Decade: Developing Countries' Stagnation in Spite of Policy Reform 1980-1998’, Journal of Economic Growth, 6: 135-57.

Eyraud, F. and C. Saget (2005). The Fundamentals of Minimum Wage Fixing, Geneva: ILO.

Fagerberg, J. and M. Godinho (2005). 'Innovation and Catching up’, in J. Fagerberg, D. Mowery and R. Nelson (eds), The Oxford Handbook of Innovation, Oxford: Oxford University Press.

Fagerberg, J., D. C. Mowery and R. R. Nelson (2005). The Oxford Handbook of Innovation, Oxford: Oxford University Press.

Fox, L. (2006). 'Minimum Wage Trends: Understanding Past and Contemporary Research', EPI Briefing Paper 178, Washington, DC: Economic Policy Institute. 
Garrett, T. A. and H. J. Wall (2006). 'Creating a Policy Environment for Entrepreneurs', Working Paper 2005-064B, St. Louis, MO: Federal Reserve Bank of St. Louis, Research Division.

Grégoire, D., R. Dery and J. P. Béchard (2001). 'Evolving Conversation: a Look at the Convergence in Entrepreneurship Research', paper presented at the Babson College Kauffman Foundation Entrepreneurship Research Conference, Jönköping International Business School, Sweden, 13-17 June.

Hampel-Milagrosa, A. (2008). 'A Combined Qualitative and Quantitative Approach to Address Gender Issues in the Doing Business Project', paper presented at the World Bank's Independent Evaluation Group (IEG) and the Doing Business Team in Washington, DC, 24-26 September.

Hart, D. M. (2003) 'Entrepreneurship Policy: What It Is and Where It Came From', in D. M. Hart (ed), The Emergence of Entrepreneurship Policy, Cambridge, UK: Cambridge University Press.

Independent Evaluation Group (IEG) (2008). Doing Business: An Independent Evaluation. Taking the Measure of the World Bank - IFC Doing Business Indicators, Washington, DC: World Bank.

International Bank for Reconstruction and Development (IBRD) and World Bank (2004). Doing Business in 2004: Understanding Regulation, Washington, DC: World Bank and Oxford University Press.

- (2005). Doing Business in 2005: Removing Obstacles to Growth, Washington, DC: World Bank and Oxford University Press.

_ (2006). Doing Business in 2006: Creating Jobs, Washington, DC: World Bank and Oxford University Press.

(2007). Doing Business 2007. How to Reform, Washington, DC: World Bank and Oxford University Press.

—_ (2008a). Doing Business 2008, Washington, DC: World Bank and Oxford University Press.

(2008b). Doing Business. Change to the Methodology, 2004-2007, available at www.doingbusiness.org/MethodologySurveys/methodologyNoteArchive.aspx, date accessed 7 February 2010.

_ (2008c). Doing Business 2009. Comparing Regulation in 181 Economies, Washington, DC: World Bank and Oxford University Press.

- (2009). Doing Business 2010. Reforming through Difficult Times, Washington, DC: World Bank and IFC and Palgrave Macmillan.

International Development Association (IDA) (2007). Country Policy and Institutional Assessments. Questionnaire 2007, available at http://siteresources.worldbank.org/IDA/Resources/CPIA2007Questionnaire.pdf, date accessed 7 February 2010.

Kanniainen, V. and C. Keuschnigg (eds) (2005) Venture Capital, Entrepreneurship, and Public Policy, Cambridge, MA and London: The MIT Press.

Kauffman Foundation (2007). 'On the Road to an Entrepreneurial Economy: A Research and Policy Guide. Version 2.0', available at www.kauffman.org (home page), date accessed 7 February 2010.

(2008). 'Kauffman Index of Entrepreneurial Activity 1996-2007', available at www.kauffman.org/pdf/KIEA_2004_R0506.pdf, date accessed 7 February 2010. 
Keen, D. (1994). The Benefits of Famine: a Political Economy of Famine and Relief in Southwestern Sudan. 1983-89, Princeton: Princeton University Press.

Kirchhoff, B. A. (1991). 'Entrepreneurship’s Contribution to Economics', Entrepreneurship Theory and Practice, 16: 93-112.

Kirzner, I. M. (1973). Competition and Entrepreneurship, Chicago: University of Chicago Press. (1979). Perception, Opportunity and Profit. Studies in the Theory of Entrepreneurship, Chicago and London: University of Chicago Press.

— (1985). Discovery and the Capital Process, Chicago and London: University of Chicago Press.

— (1992). The Meaning of Market Process, Milton Park: Routledge.

_ (2000). 'The Limits of the Market: The Real and the Imagined', in Kirzner (ed.), The Driving Force of the Market - Essays in Austrian Economics, Milton Park: Routledge.

- (2009). 'The Alert and Creative Entrepreneur: A Clarification', Small Business Economics, 32 (2): $145-52$.

Kline, S. and N. Rosenberg (1986). 'An Overview on Innovation', in R. Landau (ed.), The Positive Sum Strategy: Harnessing Technology for Economic Growth, Washington: National Academy Press.

Kuesel, C., U. Maenner and R. Meissner (ed.) (2008). The Social and Ecological Market Economy - A Model for Asian Development?, Eschborn: GTZ, Sector Network Sustainable Economic Development Asia.

Landström, H. (2004). 'Pioneers in Entrepreneurship Research', in G. Corbetta, M. Huse and D. Ravasi (eds), Crossroads of Entrepreneurship, Boston, New York, Dordrecht: Kluwer Academic Publishers.

Lee, S., and D. McCann (2007). 'Measuring Labour Market Institutions: Conceptual and Methodological Questions on: “Working Hours Rigidity”, in J. Berg and D. Kucera (eds), In Defence of Labour Market Institutions: Cultivating Justice in the Developing World, Basingstoke: Palgrave Macmillan and Geneva: ILO.

Lunghini, G., F. Silva and R. Targetti Lenti (eds) (2001). Politiche Pubbliche per il Lavoro, Bologna: Il Mulino.

Malecki, E. J. (1994) 'Entrepreneurship in Regional and Local Development', International Regional Science Review, 16: 119-153.

Mazzoleni R. and R. R. Nelson (2007). 'Public Research Institution and Economic Catch-Up', Research Policy, 36: 1512-28.

Millennium Challenge Corporation (MCC) (2003). Report on the Criteria and Methodology for Determining the Eligibility of Candidate Countries for Millennium Challenge Account Assistance in Fiscal Year 2004, available at www.mcc.gov/ date accessed 28 February 2010.

(2004). Report on the Criteria and Methodology for Determining the Eligibility of Candidate Countries for Millennium Challenge Account Assistance in Fiscal Year 2005, available at www.mcc.gov/, date accessed 28 February 2010. 
(2005). Report on the Criteria and Methodology for Determining the Eligibility of Candidate Countries for Millennium Challenge Account Assistance in Fiscal Year 2006, available at www.mcc.gov/ date accessed 28 February 2010.

(2006). Report on the Criteria and Methodology for Determining the Eligibility of Candidate Countries for Millennium Challenge Account Assistance in Fiscal Year 2007, available at www.mcc.gov/, date accessed 28 February 2010.

- (2007). Report on the Criteria and Methodology for Determining the Eligibility of Candidate Countries for Millennium Challenge Account Assistance in Fiscal Year 2008, available at www.mcc.gov/, date accessed 28 February 2010.

(2008). Report on the Criteria and Methodology for Determining the Eligibility of Candidate Countries for Millennium Challenge Account Assistance in Fiscal Year 2009, available at www.mcc.gov/, date accessed 28 February 2010.

- (2009). Report on the Criteria and Methodology for Determining the Eligibility of Candidate Countries for Millennium Challenge Account Assistance in Fiscal Year 2010, available at www.mcc.gov/, date accessed 28 February 2010.

— (2010). Selection Indicators, available at www.mcc.gov/, date accessed 28 February 2010.

McChesney, F. S. (1987). 'Rent Extraction and Rent Creation in the Economic Theory of Regulation’, Journal of Legal Studies, 16: 101-18.

McCormick, B. and J. Wahba (2000). 'Overseas Employment and Remittances to a Dual Economy’, The Economic Journal, 110 (463): 506-34.

McMillan, J. and C. Woodruff (1999a). 'Dispute Prevention without Courts in Vietnam', Journal of Law, Economics and Organization, 15: 637-58.

(1999b). 'Interfirm Relationship and Informal Credit in Vietnam', Quarterly Journal of Economic, 114: 1285-320.

— (2000). 'Private Order under Dysfunctional Public Order', Michigan Law Review, 98: 242158.

(2002). 'The Central Role of the Entrepreneurs in Transition Economies', Journal of Economic Perspectives, 16 (3): 153-70.

Metcalfe, J. S. (2004). 'The Entrepreneur and the Style of Modern Economics', in G. Corbetta, M. Huse, M. and D. Ravasi, D. (eds), Crossroads of Entrepreneurship, Boston, New York, Dordrecht: Kluwer Academic Publishers.

Morris Guerinoni, F. (2004). La Formalización de la Propiedad en el Perú: Desvelando el Misterio, Lima: COFOPRI.

Mytelka, L. (2004). 'Catching up in New Wave Technologies', Oxford Development Studies, 3 (3): 389-405.

Naudé, W. (2007). 'Peace, Prosperity, and Pro-Growth Entrepreneurship', Discussion Paper 2007/02, Helsinki: UNU-WIDER.

(2009a). 'Out with the Sleaze, in with the Ease: Insufficient for Entrepreneurial Development?’, Research Paper 2009/01, Helsinki: UNU-WIDER. 
(2009b). 'Entrepreneurship, Post-Conflict' in T. Addison and T. Brück (eds), Making Peace Work. The Challenge of Social and Economic Reconstruction, Basingstoke: Palgrave Macmillan for UNU-WIDER.

Naudé, W., A. U. Santos-Paulino and M. McGillivray (2008). 'Fragile States', Research Brief 3, Helsinki: UNU-WIDER.

Neri, M., G. Gonzaga and J. M. Camargo (2001). 'Salário Minimo, “Efeito-Farol” e Pobreza, Revista de Economia Política, 21(2): 78-90.

Niosi, J. (2008). 'Technology, Development and Innovation Systems: An Introduction', Journal of Development Studies, 44 (5): 613-21.

OECD (1992, rev. 1997) Innovation Manual: Proposed Guidelines for Collecting and Interpreting Innovation data (Oslo Manual), Paris: OECD, Directorate for Science, Technology and Industry.

— (2001a). Innovating Networks: Collaboration in National Innovation Systems, Paris: OECD.

_ (2001b). PUMA Multi-Country Business Survey Database, Paris: OECD.

- (2002). The Measurement of Scientific and Technological Activities. Proposed Standard Practice for Surveys on Research and Experimental Development: Frascati Manual, Paris: OECD.

- (2003). From Red Tape to Smart Tape: Administrative Simplification in OECD Countries, Paris: OECD.

— (2007a). Cutting Red Tape: Comparing Administrative Burdens Across Countries, Paris: OECD.

— (2007b). 'Towards Government at a Glance: Identification of Core Data and Issues Related to Public Sector Efficiency’, Working Paper 2, Paris: OECD.

(2008). OECD Framework for the Evaluation of SME and Entrepreneurship Policies and Programmes, Paris: OECD.

Parker, S. C. (2004). The Economics of Self-employment and Entrepreneurship, Cambridge: Cambridge University Press.

Rodrik, D. (2007). One Economics Many Recipes, Princeton, New Jersey: Princeton University Press.

Romer, P. M. (1990). 'Endogenous Technological Change', The Journal of Political Economy, 98: 71-102.

Rosen, S. (1997). 'Austrian and Neoclassical Economics: Any Gain from Trade?', Journal of Economic Perspective, 11 (4): 139-52.

Rosenberg, N. (1976). Perspectives on Technology, Cambridge: Cambridge University Press.

— (1982). Inside the Black Box: Technology and Economics, Cambridge: Cambridge University Press.

Schramm, C. J. (2004). 'Building Entrepreneurial Economies’, Foreign Affairs, 83: 104-15.

Schumpeter, J. A. (1934). The Theory of Economic Development, Cambridge, MA: Harvard University Press. 
Shackle, G. L. S. (1982). 'Foreword', in R. F. Hebert and A. Link (eds), The Entrepreneur: Mainstream Views and Radical Critiques, New York: Praeger Publishers.

Shane, S. A. (2008) The Illusions of Entrepreneurship. The Costly Myths that Entrepreneurs, Investors, and Policy Makers Live by, New Haven and London: Yale University Press.

Shleifer, A. and R. W. Vishny (1993). 'Corruption', Quarterly Journal of Economics, 108: 599617.

(1998). The Grabbing Hand: Government Pathologies and their Cures, Cambridge, MA: Harvard University Press.

Schulpen, L. and P. Gibbon (2002). 'Private Sector Development: Policies, Practices and Problems', World Development, 30 (1): 1-15.

Smallbone, D. and F. Welter (2001). 'The Distinctiveness of Entrepreneurship in Transition Economies’, Small Business Economics, 16 (4): 249-62.

Smith, K. (2005). 'Measuring Innovation', in J. Fagerberg, D. Mowery and R. Nelson (eds), The Oxford Handbook of Innovation, Oxford: Oxford University Press.

Stiglitz, J. E. (2006). 'Civil Strife and Economic and Social Policies', The Economics of Peace and Security Journal, 1: 5-9.

Taylor, E. J. (2006). 'International Migration and Economic Development', paper presented at the 'International Symposium on International Migration and Development', UN Population Division, Turin, Italy, 28-30 June.

USAID (2007). 'Women and Conflict', available at www.usaid.gov, date accessed 7 February 2010.

Wennekers, A. R. M. and R. Thurik (1999). 'Linking Entrepreneurship and Economic Growth', Small Business Economics, 13: 27-55.

Williamson, J. G. (1995). 'The Evolution of Global Labour Markets Since 1830: Background Evidence and Hypotheses’, Explorations in Economic History, 32: 141-96.

Wohlmuth, K. (2004). 'African Entrepreneurship and Private Sector Development: An Introduction', in K. Wohlmuth, A. Gutowski, T. Knedlik, M. Meyn and S. Pitamber (eds), African Development Perspectives Yearbook 2002/2003: African Entrepreneurship and Private Sector Development, Münster: Lit Verlag.

World Bank (WB) (2002). World Development Report 2002: Building Institutions for Markets, Oxford: Oxford University Press: World Bank.

World Bank and International Financial Corporation (WB and IFC) (2008). Doing Business 2008: Leaders from Top Reforming Emerging Markets Share Experiences at IFC-World Bank Seminar.

(2009). Doing Business. Measuring Business Regulation. Methodology and research, available at www.doingbusiness.org/MethodologySurveys/DealingLicenses.aspx, date accessed 7 February 2010. 
Table 1: The starting a business indicator

\begin{tabular}{|c|c|c|c|}
\hline INDICATOR & $\begin{array}{l}\text { BACKGROUND } \\
\text { PAPER }\end{array}$ & SUBINDICATORS & $\begin{array}{l}\text { ASSUMPTION ON THE } \\
\text { BUSINESS }\end{array}$ \\
\hline $\begin{array}{l}\text { Starting a } \\
\text { business }\end{array}$ & $\begin{array}{l}\text { The Regulation of } \\
\text { Entry } \\
\text { Djankov et al. } \\
\text { (2002) }\end{array}$ & $\begin{array}{l}\text { Number of procedures (any } \\
\text { interaction of the company } \\
\text { founders with external } \\
\text { parties) } \\
\text { Caveat: procedures that the } \\
\text { company undergoes to } \\
\text { connect electricity, water, } \\
\text { gas and waste disposal } \\
\text { services are not included } \\
\text { Time (days) }\end{array}$ & $\begin{array}{l}\text { Limited liability company (if more } \\
\text { than one, the most popular form) } \\
\text { Operates in the economy's largest } \\
\text { business city } \\
100 \% \text { domestically owned (five } \\
\text { owners, none of whom is a legal } \\
\text { entity) } \\
\text { Start up capital of } 10 \text { times income } \\
\text { per capita at the end of } 2007 \text {, paid } \\
\text { in cash } \\
\text { General industrial or commercial } \\
\text { activities, not foreign trade } \\
\text { activities and not products subject } \\
\text { to a special tax regime. No heavily } \\
\text { polluting production processes. } \\
\text { Leases the commercial plant, no } \\
\text { real estate } \\
\text { No investment incentives or any } \\
\text { special benefits } \\
\text { Between } 10 \text { and } 50 \text { national } \\
\text { employees one month after the } \\
\text { commencement of operations } \\
\text { Turnover of at least } 100 \text { times } \\
\text { income per capita } \\
\text { Company deed } 10 \text { pages long } \\
\text { The entrepreneur is aware of all } \\
\text { entry regulations and their } \\
\text { sequence from the beginning but } \\
\text { has had no prior contact with any } \\
\text { officials }\end{array}$ \\
\hline
\end{tabular}


Table 2: The employing workers indicator

\begin{tabular}{|c|c|c|c|c|c|c|}
\hline \multirow[t]{2}{*}{ INDICATOR } & \multirow{2}{*}{$\begin{array}{l}\text { BACKGROUND } \\
\text { PAPER }\end{array}$} & \multicolumn{2}{|c|}{ ASSUMPTIONS } & \multicolumn{3}{|c|}{ SUBINDICATORS } \\
\hline & & business & worker & & & \\
\hline $\begin{array}{l}\text { Employing } \\
\text { workers } \\
\text { (until DB 2006, } \\
\text { Hiring and firing } \\
\text { workers) }\end{array}$ & $\begin{array}{l}\text { The regulation of } \\
\text { Labour (Botero et } \\
\text { al. 2004) }\end{array}$ & $\begin{array}{l}\text { Limited liability } \\
\text { company in the } \\
\text { country's most } \\
\text { populous city } \\
\text { 100\% domestically } \\
\text { owned } \\
\text { Operates in the } \\
\text { manufacturing } \\
\text { sector } \\
60 \text { employees } \\
\text { (201 until DB } \\
2009 \text { ) } \\
\text { Subject to } \\
\text { collective } \\
\text { bargaining } \\
\text { agreements in } \\
\text { countries where } \\
\text { such agreements } \\
\text { cover more than } \\
\text { half the } \\
\text { manufacturing } \\
\text { sector and apply } \\
\text { even to firms not } \\
\text { party to them } \\
\text { Abides by every }\end{array}$ & $\begin{array}{l}42 \text { year old, } \\
\text { non-executive, } \\
\text { full-time, male } \\
\text { employee } \\
\text { Has worked at } \\
\text { the same } \\
\text { company for } 20 \\
\text { years } \\
\text { Salary plus } \\
\text { benefits equal } \\
\text { to the country's } \\
\text { average wage } \\
\text { during the entire } \\
\text { period of his } \\
\text { employment } \\
\text { Lawful citizen, } \\
\text { same race and } \\
\text { religion of the } \\
\text { majority of the } \\
\text { country's } \\
\text { population } \\
\text { Resides in the } \\
\text { country most } \\
\text { populous city }\end{array}$ & $\begin{array}{l}\text { Rigidity of } \\
\text { employme } \\
\text { nt index }\end{array}$ & $\begin{array}{l}\text { Rigidity of } \\
\text { hours index }\end{array}$ & $\begin{array}{l}\text { Fixed term contracts } \\
\text { for permanent tasks } \\
\text { Max. cumulative duration } \\
\text { of fixed term contracts } \\
\text { Ratio of minimum wage for } \\
\text { a trainee } \\
\text { or first employee to the } \\
\text { average value added per } \\
\text { worker } \\
\text { Night work unrestricted } \\
\text { Weekend work unrestricted } \\
\text { Workweek can consist of } \\
5.5 \text { days } \\
\text { Workweek can extend to } 50 \\
\text { hours } \\
\text { (for seasonal increase in } \\
\text { production, } 2 \text { months a } \\
\text { year) } \\
\text { Paid annual vacation } 21 \\
\text { working days or fewer } \\
\text { Redundancy disallowed as } \\
\text { basis for terminating } \\
\text { workers } \\
\text { Notify a third party to } \\
\text { terminate one redundant } \\
\text { worker } \\
\text { Notify a third party to } \\
\text { terminate }\end{array}$ \\
\hline
\end{tabular}


law and regulation

but does not grant

workers more

benefits than

mandated by law

regulation or (if

applicable)

collective

bargaining

agreement a group of 25 redundant

workers

Approval from a third party

to terminate one redundant

worker

Approval from a third party

to terminate a group of 25

redundant workers

Reassignment or retraining

options before redundancy

termination

Priority rules apply for

redundancies

Priority rules apply for

reemployment

Non-wage All social security payments and payroll

labour taxes associated with hiring an employee (\%

cost of the worker's salary)

Firing cost Cost of advance notice requirements,

severance payments and penalties due

when terminating a redundant worker 